\title{
Effects of therapeutic hypothermia and kinetics of serum protein S10oB after cardiopulmonary resuscitation
}

BY ÁKOS MÉREI, BÁLINT JÁNOS NAGY, GÁBOR LÁSZLÓ WOTH, NÓRA ZSIDÓ, JÁNOS LANTOS, DIANA MÜHL

\section{Abstract}

Introduction. Post-resuscitation care is regulated by international guidelines. A milestone of these is the application of therapeutic hypothermia (TH). The aims of our study were: to determine the 30-daymortality for our patients, to monitor the efficacy and effects of $\mathrm{TH}$, and to investigate serum protein $\mathrm{S} 100 \mathrm{~B}$ - as an early prognostic marker.

Materials and Methods. In our study, 57 patients, treated after cardiopulmonary resuscitation (CPR) on a multidisciplinary intensive care unit, were included. Patients were divided into groups who received and who didn't receive TH. 30-day-mortality was determined as an endpoint. Effects of TH were monitored using statistical analysis according to clinical parameters and laboratory tests. Serum protein S10oB levels were measured with ELISA technique on 20 randomised patients at admission and the $1^{\text {st }}, 3^{\text {rd }}$ and $5^{\text {th }}$ day after CPR. 
Results. Total 30-day-mortality was $74 \%$. TH did not reduced the 30-daymortality (73\% vs. 74\%, p>0.05). We found a significant correlation between $\mathrm{TH}$ and serum lactate concentration after admission (oh, $\mathrm{p}=0.006)$ and at $12(\mathrm{p}=0.045)$ and $36(\mathrm{p}=0.049)$ hours after CPR. On the $3^{\text {rd }}(\mathrm{p}=0.005)$ and $4^{\text {th }}(\mathrm{p}=0.043)$ day after CPR, as a result of $\mathrm{TH}$, platelet count was significantly higher compared to normothermic samples. There was no significant difference in protein $\mathrm{S1OoB}$ levels between the normothermic and TH group and protein S10oB levels did not correlate with 30-day-mortality.

Conclusion. Despite recommendations of international guidelines, we cannot prove the beneficial effect of $\mathrm{TH}$, or a correlation of protein $\mathrm{S} 100 \mathrm{~B}$ levels with a positive outcome.

Key words: cardiac arrest, cardiopulmonary resuscitation, postresuscitation care, therapeutic hypothermia, protein $\mathrm{S1OoB}$

\section{Introduction}

Ischaemic heart disease is the leading cause of mortality worldwide. In Europe cardiovascular disorders are responsible for $40 \%$ of total mortality. In developed countries the major cause of out-of-hospital sudden death is cardiac arrest with a survival rate of 5-35\%. After cardiopulmonary resuscitation (CPR) the rate of the return of spontaneous circulation (ROSC) is $25-50 \%$, but the chance that patients survive without neurological deficit is less than 10\%. (1) CPR is regulated by international guidelines. It is well known that post-resuscitation therapy basically determines the neurologic outcome. (2-4)

Hypothermia is the state, when body core temperature is below $36^{\circ} \mathrm{C}$. Hypothermia can be classified by its effects on the human body (mild 32$34^{\circ} \mathrm{C}$, moderate $28-32^{\circ} \mathrm{C}$, deep $<28^{\circ} \mathrm{C}$ ). (5) Since the $195 \mathrm{Os}$, moderate hypothermia has been used in cardiac surgery to prevent cerebral ischaemia. It was also applied after cardiac arrest (CA), but has been stopped due to unclear benefits. (6) Therapeutic hypothermia (TH) after ROSC has been recommended by the International Liaison Committee on Resuscitation (ILCOR) since 2003 and by the European Resuscitation 
Council (ERC) since 2005. Since 2010 ERC has recommended the use of TH after CPR ( $32-34^{\circ} \mathrm{C}$ core temperature for $12-24$ hours). TH could be beneficial following primary cerebral injury by preventing further neuronal damage. $(5,7)$ After ROSC one of the major causes of mortality is cerebral injury (68\% of out-of-hospital, $23 \%$ of in-hospital cases). (4) Former attempts to determine the level of cerebral injury and prognosis, within the first 24 hours with clinical neurological or electrophysiological methods were unreliable. Biochemical markers, such as neuron specific enolase (NSE) and protein S1OoB (PS1OoB), may indicate the level of cerebral injury and prognosis in an early phase. $(8,9)$

In our study the aims were to investigate the survival rate of patients after CPR, ROSC, to determine the efficiency of TH in our practice, to monitor the effects of TH and to measure the level of PS10oB as an early predictor of prognosis.

\section{Materials and Methods}

\section{Patient selection}

Our study was carried out in accordance with the ethical guidelines of the 2005 Declaration of Helsinki, and permission was obtained from the Institutional Scientific and Human Research Ethics Committee of the University of Pécs. Patients ( $\mathrm{n}=57$ ) treated on the multidisciplinary intensive care unit (ICU) of University of Pécs between June 2009 and February 2012 after CPR, ROSC were included in the study. In our patient group the cause of CA and the initial cardiac electrical activity was heterogeneous (table 1A) Patients with chronic disorders were not excluded (table 1B). A written informed consent was acquired after providing detailed information about the study design and blood sampling to the closest relative of unconscious patients according to national law. In the case of each patient, CPR, defibrillation, drug administration were carried out under the advanced life support recommendation of the Hungarian Resuscitation Committee which complies with the ERC guideline. (10) Different types of initial cardiac rhythm were not excluded. After ROSC ICU therapy was started at the earliest time. To reach the recommended level of $\mathrm{TH}, 3 \mathrm{Oml} / \mathrm{kg}$ of cold $\left(4^{\circ} \mathrm{C}\right)$ 0.9\% Saline infusion and additional external cooling (cooler blocks 
over great blood vessels) were used. TH was maintained for 24 hours. Core temperatures of the patients were measured at the upper oesophagus. During ICU therapy regular laboratory blood tests (including blood gas parameters, lactate levels, blood cell count, electrolyte levels, C-reactive protein and organ function specific parameters) were taken, blood samples were collected via an arterial cannula, which were inserted at the time of ICU admission according to local protocol. To compare the general condition of patients, the New Simplified Acute Physiology Score (SAPSII) was measured in each case. Patients were separated according to 30-day-mortality. To monitor patient's early neurological state, the Glasgow Coma Scale (GCS) was used. Investigation of long-term neurological outcome and functional capacity of the survivors was not the aim of the study.

\section{Protein S1ooB assays}

20 randomised patients were chosen to determine PS10oB. Blood samples were collected within 2 hours after CPR, intensive care unit admission ( $1^{\text {st }}$ sample) and after 24,72 and 120 hours $\left(2^{\text {nd }}, 3^{\text {rd }}, 4^{\text {th }}\right.$ samples). Native blood samples were centrifuged (1500g, 10min) and stored at $-80^{\circ} \mathrm{C}$ until analysis. PS10oB quantitative measurement was performed by sandwich enzyme immunoassay according to manufacturer's instructions (RD19209010oR, BioVendor Laboratornímedicína a.s., Brno, Czech Republic). The concentrations of PS10oB (ng/l) were determined spectrophotometrically at 450nm absorption wavelength in comparison with the standard curve.

Statistical analysis

For statistical analysis SPSS v21 for Windows (IBM SPSS Statistics) was used. Data were expressed as minimum, maximum and median. Nonparametric data were analysed with Mann-Whitney U test. In calculations, $\mathrm{p}<0.05$ was considered significant.

\section{Results}

Patient mortality rate

Among the 57 patients (female: 19, male: 38 ), the overall mean age was 62 years, and there was no difference between the two genders (female: 
64y, male: 61y). The duration of CPR was between 1 and 50 minutes (mean: 14.5 minutes). After CPR, TH was applied on 22 patients. The total 30-day-mortality was $74 \%$. There was no difference in the 30-daymortality between the two genders and the age of the patients did not influence the 30-day-mortality. In our study, TH did not reduce the $30-$ day-mortality (73\% vs. 74\%). Neither the duration of CPR nor the initial cardiac electrical activity (ventricular fibrillation, pulseless electrical activity or asystole) influenced the mortality ( $73 \%$ vs $71 \%$ vs $78 \%$ ). SAPSII values were not altered between survivors and non-survivors. Glasgow Coma Scale values on ICU admission were significantly related to 30-daymortality ( $\mathrm{p}=0.047)$. To differentiate patients, a GCS cut-off-point of 6 was established. In the GCS $<6$ group the mortality was significantly higher than in $\mathrm{GCS} \geq 6$ group (table 2 ).

\section{Effects of TH}

In the TH group, serum lactate concentration after ICU admission (oh, $\mathrm{p}=0.006)$ and at $12(\mathrm{p}=0.045)$ and $36(\mathrm{p}=0.049)$ hours after ROSC was significantly higher compared to NT samples. The median serum lactate concentration after $\mathrm{TH}$ was more than twice that in the normothermic (NT) group, at the first measurement ( $6.3 \mathrm{mmol} / \mathrm{l} \mathrm{vs} 2.8 \mathrm{mmol} / \mathrm{l}) . \mathrm{In}$ both groups, lactate concentrations reached normal range after 12 hours and stayed within this range in the further samples (figure 1). Medians of serum bicarbonate $\left(\mathrm{HCO}_{3}\right)$ in the $\mathrm{TH}$ group showed an increasing tendency in the first 96 hours after ROSC. In NT patients, $\mathrm{HCO}_{3}$ levels increased to normal serum range until the $12^{\text {th }}$ hour, however, in the TH group elevation was more sustained (normalisation at $36^{\text {th }}$ hour). After that, $\mathrm{HCO}_{3}$ concentrations rose to higher than normal range (from the $48^{\text {th }}$ hour in NT group vs. $72^{\text {th }}$ hour in TH group (figure 2).On the $3^{\text {rd }}$ $(\mathrm{p}=0.005)$ and $4^{\text {th }}(\mathrm{p}=0.043)$ days after ROSC, as a result of $\mathrm{TH}$, platelet count was significantly higher compared to NT samples. In the TH group, median platelet count was higher in each measurement, although neither in NT nor after TH, could higher-than-normal levels be measured (figure 3).

\section{Protein S1ooB levels}

Levels of serum PS10oB measured in the $4^{\text {th }}$ samples showed a 
significant decrease compared to the $1^{\mathrm{St}}(\mathrm{p}=0.001)$ and $2^{\text {nd }}(\mathrm{p}=0.019)$

samples (figure 4). Among non-survivors, in the $1^{\text {st }}$ and $2^{\text {nd }}$ samples, a tendency to higher serum levels was observed, which disappeared until the $3^{\text {rd }}$ and $4^{\text {th }}$ samples, however the difference was not significant between survivors and non-survivors (figure 5 ). There was no significant difference in PS1OoB levels between the NT and TH group (figure 6), but among survivors a marked lower tendency in the $\mathrm{TH}$ group occurred (figure 7).

\section{Discussion}

Patients' mortality rate

The incidence of out-of-hospital cardiac arrest (CA) is approximately 350,000 per year in Europe. (11) Corner stones of management are: early recognition, early basic life support, early defibrillation (if necessary) and early post-resuscitation therapy. After CA global anoxia occurs. The extent of cellular injury is determined by the duration and rate of hypoxia, individual cellular resistance and the extracellular environment. (4)

Cerebral dysfunction which develops after CA can be completely reversible within the first 5 minutes. After this period, ROS production and hypoxia-generated calcium-ion movement causes excitatory neurotransmitter (e.g. glutamate) release leading to further neuronal injury. Most hypoxia-sensitive neurons are located in the basal ganglia, hippocampus and cerebellum. (11) After CA, central nervous system dysfunction may manifest at variable levels of cognitive dysfunction: myoclonus, convulsions, coma and brain death. Cerebral injury may occur via microcirculation- and autoregulation disturbances, hyperpyrexia, hypoxia, hypercarbia or hyperglycaemia. (8)

According to the ERC guideline, published in 2010, TH improves neurological outcome after CPR, consequently a reduction in total mortality has been described in several publications. (12-16) In contrast, in the present study TH did not alter 30-day-mortality. This might have been influenced by the low number of patients and the efficiency of the 
cooling method in our unit, although in a recent randomised study Nielsen et al. (17) found that after out-of-hospital cardiac arrest of presumed cardiac cause, hypothermia at a targeted temperature of $33^{\circ} \mathrm{C}$ did not confer a benefit as compared with a targeted temperature of $36^{\circ} \mathrm{C}$. In paediatric practice, $\mathrm{TH}$ and consequent microcirculatory impairment was associated with a higher mortality rate. (18) In contrast with Arrich et al., (19) in the present study 30-day-mortality was not influenced by the gender and age of the patients. The duration of CPR, and initial cardiac activity did not significantly influence 30-day-mortality in our study, but earlier findings reported elevated mortality rate after nonshockable rhythms (20) and the duration of CPR as an independent predictor of mortality. $(21,22)$ It is well known that the original ILCOR guideline recommended $\mathrm{TH}$ after ventricular fibrillation but for other rhythms the „may also be beneficial” statement was used. (6) However, over recent years, $\mathrm{TH}$, after non-shockable rhythms, was found to improve outcomes. (23) A GCS $<6$ consciousness on ICU admission was related to significantly higher mortality rates compared to the GCS $\geq 6$ group. Hassan et al. (24) found the same relationship between GCS score and mortality. In recent years „Full Outline of UnResponsiveness” (FOUR) score has been widely used, which can eliminate the incorrect assignment of verbal function in intubated patients $(25,26)$ but positive correlation between BIS values and GCS scores was also found, and BIS values may predict the post-resuscitative outcome. (27)

\section{Effects of TH}

Today TH after ROSC is recommended by international guidelines. Since $2010 \mathrm{ERC}$ recommends the use of $\mathrm{TH}$ after $\mathrm{CPR}\left(32-34^{\circ} \mathrm{C}\right.$ core temperature for 12-24 hours) as a beneficial method after primary cerebral injury by preventing further neuronal damage. $(5,7)$

In the present study, serum lactate levels in the TH group were significantly higher than in the NT group on ICU admission and in the $12^{\text {th }}$ and $36^{\text {th }}$ hours after ROSC. In contrast, Bernard et al. (11) measured a significant difference just in the $18^{\text {th }}$ and $24^{\text {th }}$ hour after ROSC. This alteration may be due to the duration of applied $\mathrm{TH}$ (12h vs $24 \mathrm{~h}$ in our practice). In parallel, we found a prolonged normalisation of serum lactate levels in the TH group, which can be explained by decreased 
lactate-clearance caused by TH. In the present study, lower

normalization tendency of serum bicarbonate concentrations was measured in the TH group compared to the NT group, which was associated with a longer elevation to normal values. This may be influenced by a decreased dissociation rate of carbonic acid at lower temperatures. $(4,28)$ Contrary to an earlier publication (29) - where cold intravenous fluid volume was applied to reach $\mathrm{TH}$, as a result a lower platelet count was measured - we found higher thrombocyte counts in the TH group. In an attempt to find an explanation, no completely acceptable reasons were found, further investigation is required.

\section{Protein S1ooB levels}

PS10oB is a small acidic protein, a member of the calcium-binding protein family. PS10oB is synthesized by astrocytes, oligodendrocytes and Schwann-cells. This protein is the biochemical marker of the integrity of the blood-brain-barrier (BBB). After BBB dysfunction, the PS10oB level increases in the cerebrospinal fluid and serum. High PS10oB levels correlate with poor survival. (30) Compared to NSE (a dimer enzyme (2-phosph-D-glycerate-dehydrogenase), synthesized by neuroectodermal-origin-cells, also a serum marker of cerebral injury), PS10oB was found to be more reliable as an early predictor of poor neurological outcome after CA. $(31,32)$

We measured decreasing levels of PS10oB, from the $1^{\text {st }}$ to $4^{\text {th }}$ samples, that can comply with the relative short half-life (120min) of this protein in the serum. (30) Several human investigations have found that PS10oB is a good early predictor of mortality after ROSC (31-34) however, complete agreement cannot be found. In the present investigation there was no significant alteration in PS10oB between the survivor and nonsurvivors groups, based on 30-day-mortality. Our result can be compared to the findings of Song et al. (35) Among 151 patients who experienced out-of -hospital resuscitation, they found that higher levels of PS1OoB at the start of CPR were significantly associated with lower survival on admission, but the PS10oB levels were not different for 1-month survival rates between survivors and non-survivors. We could not measure differences in PS100B levels in the TH and NT groups which might be influenced by the low number of cases, and the same mortality observed 
in the groups.

\section{Conclusions}

Despite recommendations of international guidelines, efficacy of TH in the ICU after CPR has become questionable in recent years. Results of different trials may be conflicting. Such a tendency can be recognised in connection with the clinical use of PS100B, as an early predictor of mortality and neurological outcome after CA, ROSC. Despite a lack of evidence, the dominance of findings in support seems to be strong. In our study we could not prove the beneficial effect of $\mathrm{TH}$, or a relationship between PS10oB levels and positive outcome, although the low case number was a limitation of the present investigation.

\section{Acknowledgements}

We would like to thank all the nurses and technical co-workers of the Department of Anaesthesia and Intensive Therapy, as well as Csilla Fajtik, from the Department of Surgical Research and Techniques, for their supportive help in completing the present study.

\section{References}

1. Reith S, Marx N. Therapeutische Hypothermie nach Reanimation TT Therapeutic hypothermia after resuscitation. Dtsch med Wochenschr 2010;135(47):2355-60.

2. Nolan JP, Soar J, Zideman DA, Biarent D, Bossaert LL, Deakin C, et al. Kurzdarstellung. Notfall + Rettungsmedizin [Internet]. 2010 Nov $13 ; 13(7): 515-22$.

3. Orban JC, Cattet F, Lefrant JY, Leone M, Jaber S, Constantin JM, et al. The Practice of Therapeutic Hypothermia after Cardiac Arrest in France: A National Survey. PLoS One; 2012 Jan;7(9):e45284.

4. Neumar RW, Nolan JP, Adrie C, Aibiki M, Berg R a, Böttiger BW, et al. Post-cardiac arrest syndrome: epidemiology, pathophysiology, treatment, and prognostication. A consensus statement from the International Liaison Committee on Resuscitation (American Heart Association, 
Australian and New Zealand Council on Resuscitation. Circulation 2008 Dec 2 118(23):2452-83.

5. Schneider a, Popp E, Teschendorf P, Böttiger BW. Therapeutische Hypothermie. Anaesthesist 2008;57(2):197-206; quiz 207-8.

6. Nolan JP, Morley PT, Vanden Hoek TL, Hickey RW, Kloek WGJ, Billi J, et al. Therapeutic hypothermia after cardiac arrest. An advisory statement by the Advanced Life Support Task Force of the International Liaison Committee on Resuscitation. Resuscitation $2003 \mathrm{Jul}$ $8 ; 57(3): 231-5$.

7. Gunn a. J, Thoresen M. Hypothermic Neuroprotection. NeuroRx 2006;3(2):154-69.

8. Deakin CD, Nolan JP, Soar J, Sunde K, Koster RW, Smith GB, et al. Erweiterte Reanimationsmaßnahmen für Erwachsene (,advanced life support“). Notfall + Rettungsmedizin 2010 Nov 13;13(7):559-620.

9. Böttiger BW, Möbes S, Glätzer R, Bauer H, Gries a, Bärtsch P, et al. Astroglial protein $\mathrm{S}-100$ is an early and sensitive marker of hypoxic brain damage and outcome after cardiac arrest in humans. Circulation 2001 Jun 5;103(22):2694-8.

10. Nolan JP, Soar J, Zideman D a, Biarent D, Bossaert LL, Deakin C, et al. European Resuscitation Council Guidelines for Resuscitation 2010 Section 1. Executive summary. Resuscitation 2010 Oct;81(10):1219-76.

11. Bernard SA, Gray TW, Buist MD, Jones BM, Silvester W, Gutteridge G SK. Treatment of comatose survivors of out-of-hospital cardiac arrest with induced hypothermia. N Engl J Med 2002;346(8):557-63.

12. THE HYPOTHERMIA AFTER CARDIAC ARREST STUDY GROUP. Mild therapeutic hypothermia to improve the neurologic outcome after cardiac arrest. N Engl J Med 2002;346(8):549-56.

13. Oddo M, Schaller M-D, Feihl F, Ribordy V, Liaudet L. From evidence to clinical practice: Effective implementation of therapeutic hypothermia to improve patient outcome after cardiac arrest. Crit Care Med 2006 Aug ;34(7):1865-73.

14. Bernard S a, Jones BM, Horne MK. Clinical trial of induced hypothermia in comatose survivors of out-of-hospital cardiac arrest. Ann Emerg Med 1997 Aug;30(2):146-53.

15. 15. Storm C, Steffen I, Schefold JC, Krueger A, Oppert M, Jörres A, et al. Mild therapeutic hypothermia shortens intensive care unit stay of 
survivors after out-of-hospital cardiac arrest compared to historical controls. Crit Care 2008 Jan;12(3):R78.

16. 16. Don CW, Longstreth W, Maynard C, Olsufka M, Nichol G, Ray T, et al. Active surface cooling protocol to induce mild therapeutic hypothermia after out-of-hospital cardiac arrest: A retrospective before-and-after comparison in a single hospital. Crit Care Med 2009;37(12):3062-9.

17. 17. Nielsen N, Wetterslev J, Cronberg T, Erlinge D, Gasche Y, Hassager C, et al. Targeted Temperature Management at $33^{\circ} \mathrm{C}$ versus $36^{\circ} \mathrm{C}$ after Cardiac Arrest. N Engl J Med 2013;369(23):2197-206.

18. 18. Buijs EAB, Verboom EM, Top APC, Andrinopoulou E-R, Buysse CMP, Ince $\mathrm{C}$, et al. Early microcirculatory impairment during therapeutic hypothermia is associated with poor outcome in post-cardiac arrest children: A prospective observational cohort study. Resuscitation 2014;85(3):397-404.

19. Arrich J, Sterz F, Fleischhackl R, Uray T, Losert H, Kliegel A, et al. Gender modifies the influence of age on outcome after successfully resuscitated cardiac arrest: a retrospective cohort study. Medicine (Baltimore) 2006 Sep;85(5):288-94.

20. Meaney P a, Nadkarni VM, Kern KB, Indik JH, Halperin HR, Berg R a. Rhythms and outcomes of adult in-hospital cardiac arrest. Crit Care Med 2010 Jan;38(1):101-8.

21. Khan NU, Razzak J a, Ahmed H, Furqan M, Saleem AF, Alam H, et al. Cardiopulmonary resuscitation: outcome and its predictors among hospitalized adult patients in Pakistan. Int J Emerg Med 2008 Apr;1(1):27-34.

22. Kutsogiannis DJ, Bagshaw SM, Laing B, Brindley PG. Predictors of survival after cardiac or respiratory arrest in critical care units. Can Med Assoc J 2011 Oct;183(14 ):1589-95.

23. Lundbye JB, Rai M, Ramu B, Hosseini-Khalili A, Li D, Slim HB, et al. Therapeutic hypothermia is associated with improved neurologic outcome and survival in cardiac arrest survivors of non-shockable rhythms. Resuscitation 2012;83(2):202-7.

24. Hassan TB, Hickey FG, Goodacre S, Bodiwala GG. Prehospital cardiac arrest in Leicestershire. J Accid Emerg Med 1996;251-5.

25. Wijdicks EFM, Bamlet WR, Maramattom B V, Manno EM, McClelland RL. Validation of a new coma scale: The FOUR score. Ann Neurol 
2005;58(4):585-93.

26. Yannopoulos D, Kotsifas K, Aufderheide TP, Lurie KG. Cardiac arrest, mild therapeutic hypothermia, and unanticipated cerebral recovery.

Neurologist 2007 Nov;13(6):369-75.

27. Liu H, Liu Y, Xu Y, Xue Y. Prognostic evaluation of bispectral index in patients following cardiopulmonary resuscitation. Exp Ther Med 2013 Mar;5(3):907-11.

28. Bach F, Mertzlufft F. Therapeutic hypothermia and acid-base management. Anaesthesist 2007 Apr;56(4):366-70.

29. Spiel AO, Kliegel A, Janata A, Uray T, Mayr FB, Laggner AN, et al. Hemostasis in cardiac arrest patients treated with mild hypothermia initiated by cold fluids. Resuscitation 2009;80(7):762-5.

30. Rothermundt M, Peters M, Prehn JHM, Arolt V. S10oB in brain damage and neurodegeneration. Microsc Res Tech 2003;60(6):614-32.

31. Schoerkhuber W, Kittler H, Sterz F, Behringer W, Holzer M, Frossard M, et al. Time course of serum neuron-specific enolase. A predictor of neurological outcome in patients resuscitated from cardiac arrest. Stroke 1999 Aug 1;30(8):1598-603.

32. Shinozaki K, Oda S, Sadahiro T, Nakamura M, Abe R, Nakada T, et al. Serum S-100B is superior to neuron-specific enolase as an early prognostic biomarker for neurological outcome following cardiopulmonary resuscitation. Resuscitation 2009;80(8):870-5.

33. Rainey T, Lesko M, Sacho R, Lecky F, Childs C. Predicting outcome after severe traumatic brain injury using the serum S100B biomarker: Results using a single (24h) time-point. Resuscitation 2009;80(3):341-5.

34. Bloomfield SM, McKinney J, Smith L, Brisman J. Reliability of S10oB in predicting severity of central nervous system injury. Neurocrit Care 2007 Jan;6(2):121-38.

35. Song KJ, Shin S Do, Ong MEH, Jeong JS. Can early serum levels of S10oB protein predict the prognosis of patients with out-of-hospital cardiac arrest? Resuscitation 2010;81(3):337-42. 


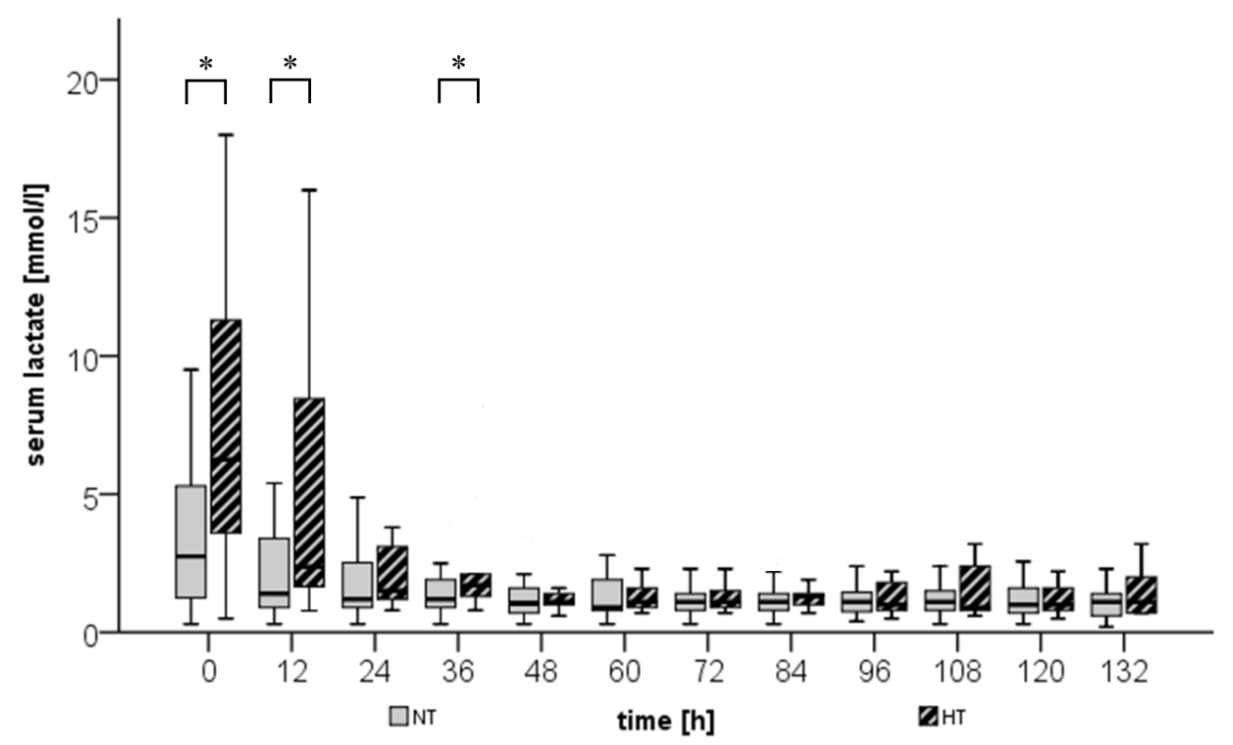

Figure 1. Serum lactate concentrations of normothermic (NT-grey boxes) and therapeutic hypothermia (TH-striped boxes) groups. Data are expressed as median and inter-quartile range (IQR; standard $25^{\text {th }}-75^{\text {th }}$ percentile and $5^{\text {th }}$ and $95^{\text {th }}$ confidence interval). ${ }^{*} \mathrm{p}<0.05$ NT vs. TH

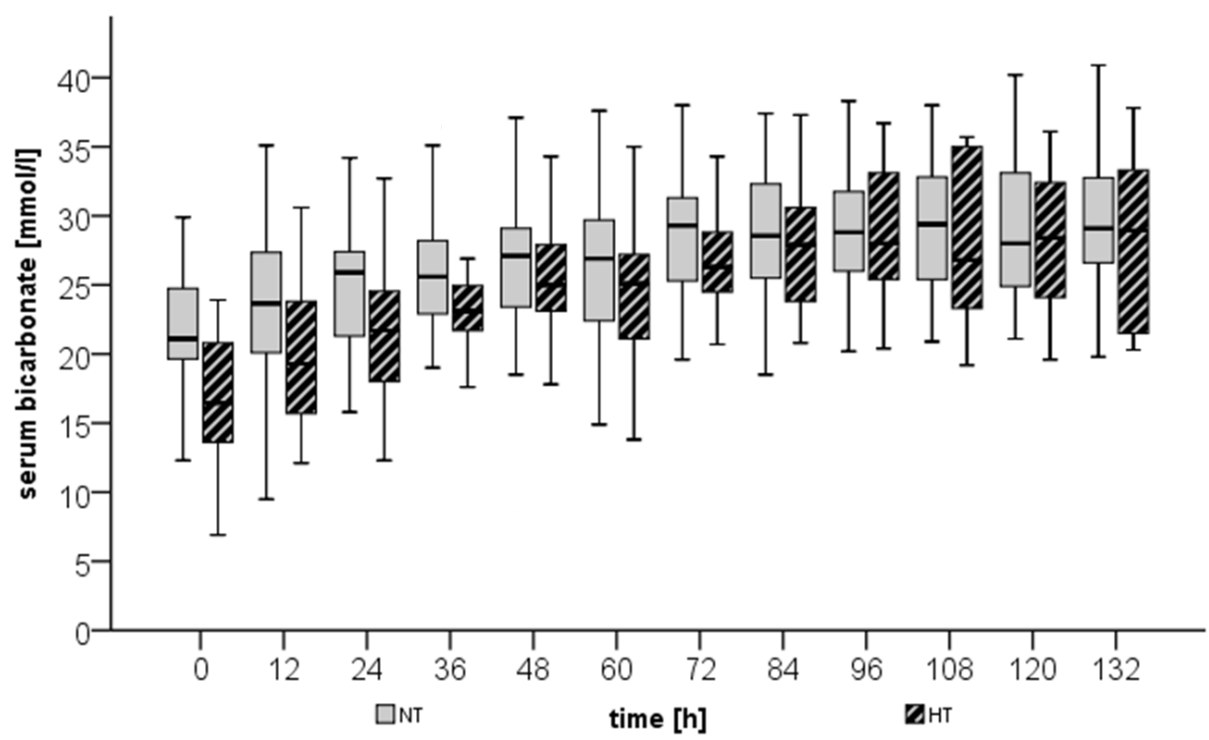

Figure 2. Serum bicarbonate concentrations of normothermic (NT-grey boxes) and therapeutic hypothermia (TH-striped boxes) groups. Data are expressed as median and inter-quartile range (IQR; standard $25^{\text {th }}-75^{\text {th }}$ percentile and $5^{\text {th }}$ and $95^{\text {th }}$ confidence interval). 


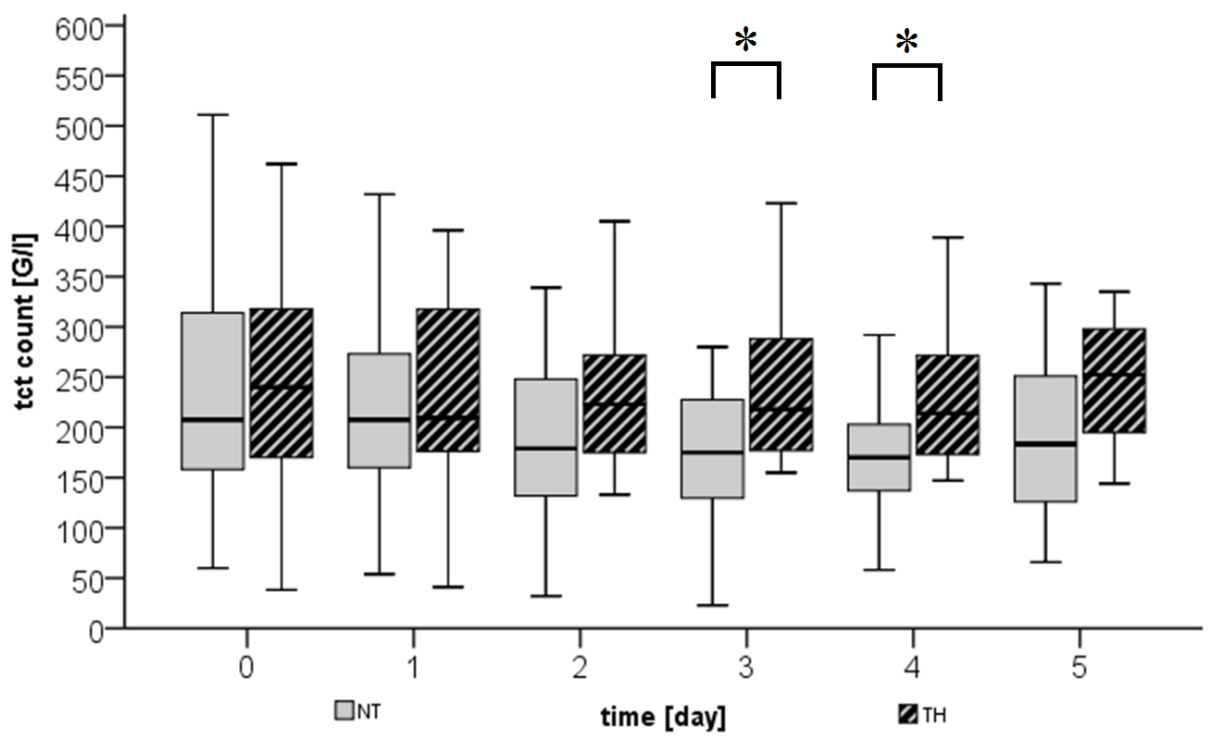

Figure 3. Thrombocyte count of normothermic (NT-grey boxes) and therapeutic hypothermia (TH-striped boxes) groups. Data are expressed as median and inter-quartile range (IQR; standard $25^{\text {th }}-75^{\text {th }}$ percentile and $5^{\text {th }}$ and $95^{\text {th }}$ confidence interval). ${ }^{*} \mathrm{p}<0.05$

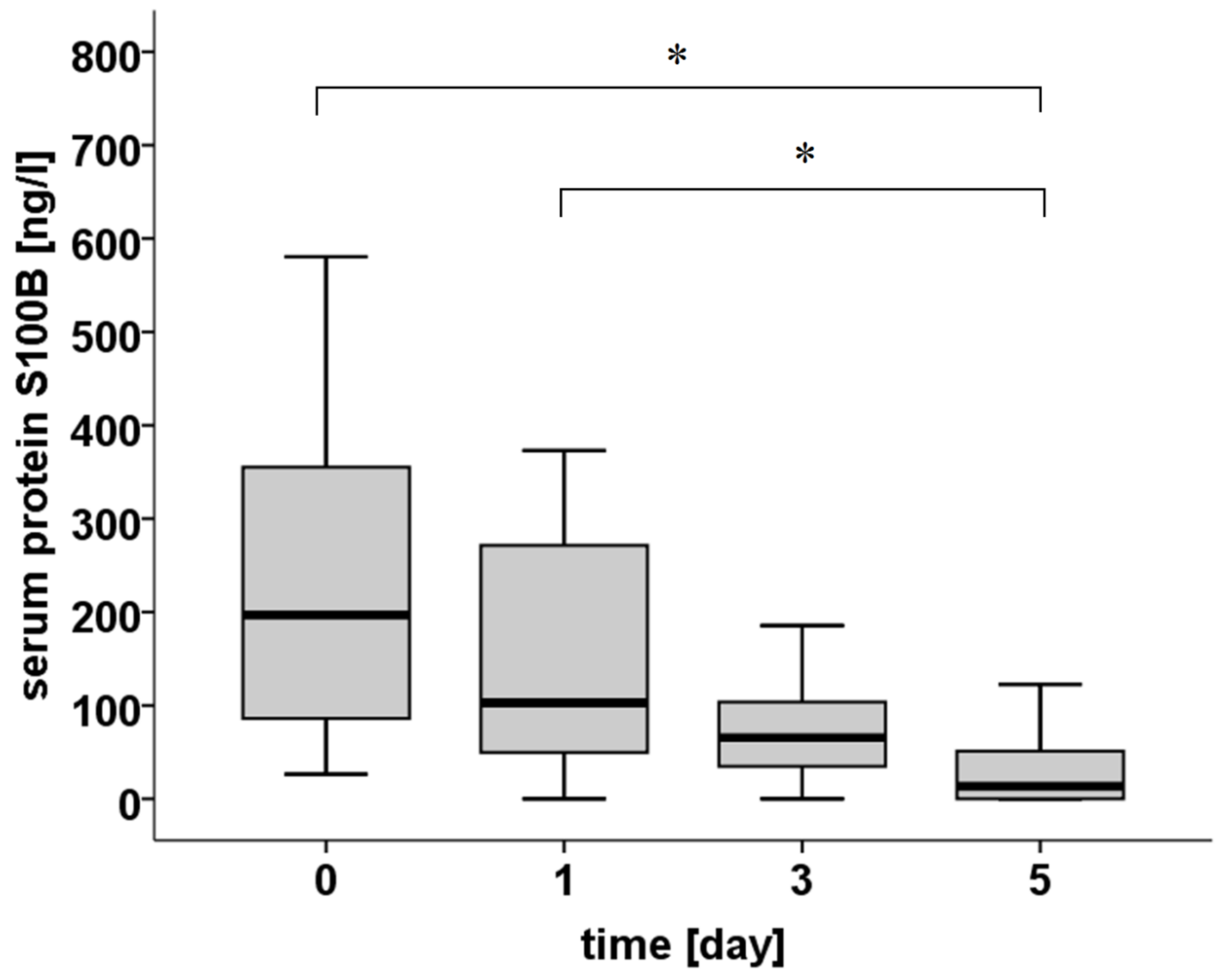

Figure 4. Serum protein S10oB levels in study patients. Data are expressed as median and inter-quartile range (IQR; standard $25^{\text {th }}-75^{\text {th }}$ percentile and $5^{\text {th }}$ and $95^{\text {th }}$ confidence interval). ${ }^{*} \mathrm{p}<0.05$, ns: non- 
significant

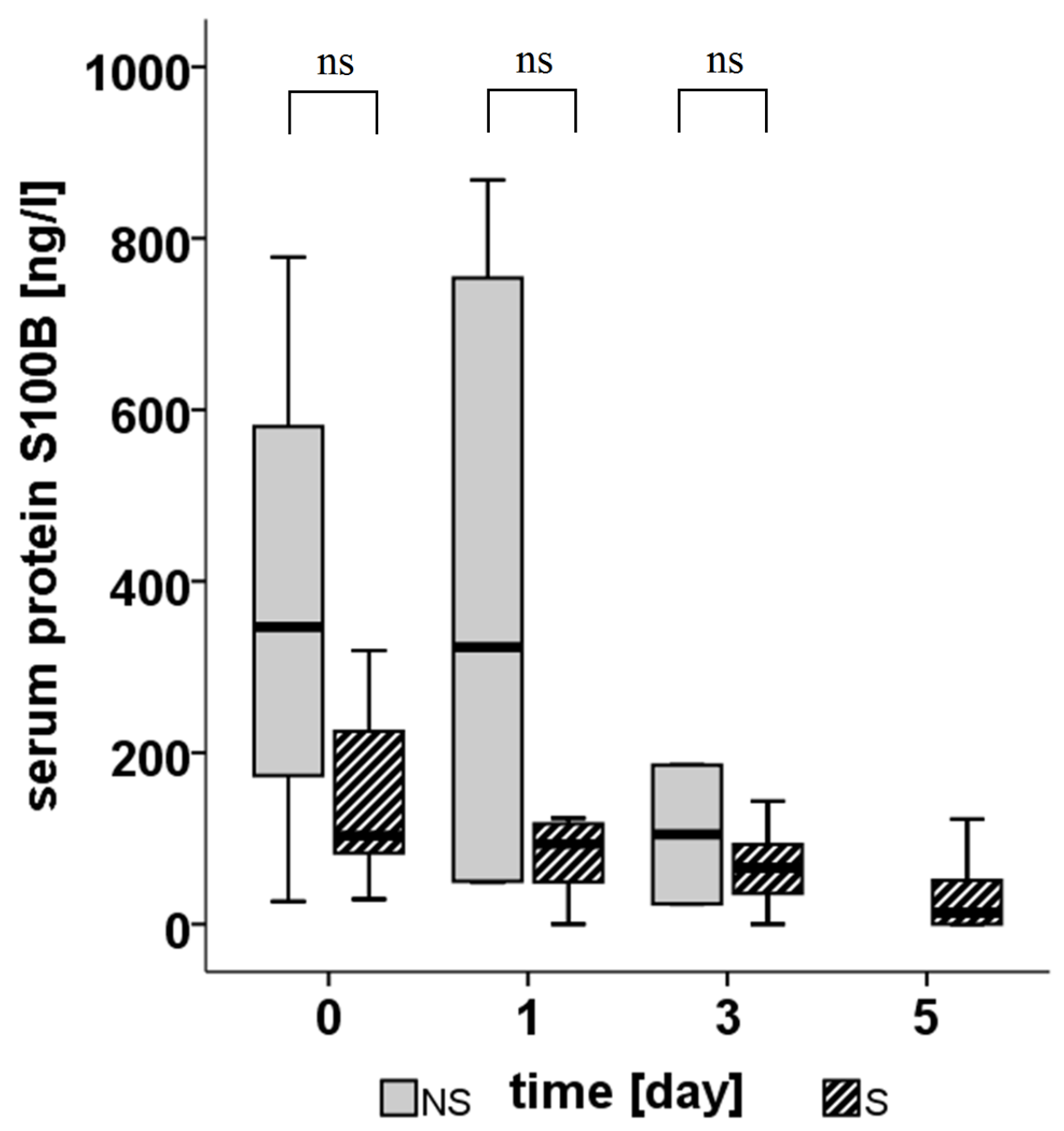

Figure 5. Serum protein S10oB levels among non-survivors (NS - grey boxes) and survivors ( $\mathrm{S}$ - striped boxes) Data are expressed as median and inter-quartile range (IQR; standard $25^{\text {th }}-75^{\text {th }}$ percentile and $5^{\text {th }}$ and $95^{\text {th }}$ confidence interval). ${ }^{*} \mathrm{p}<0.05$, ns: non-significant 


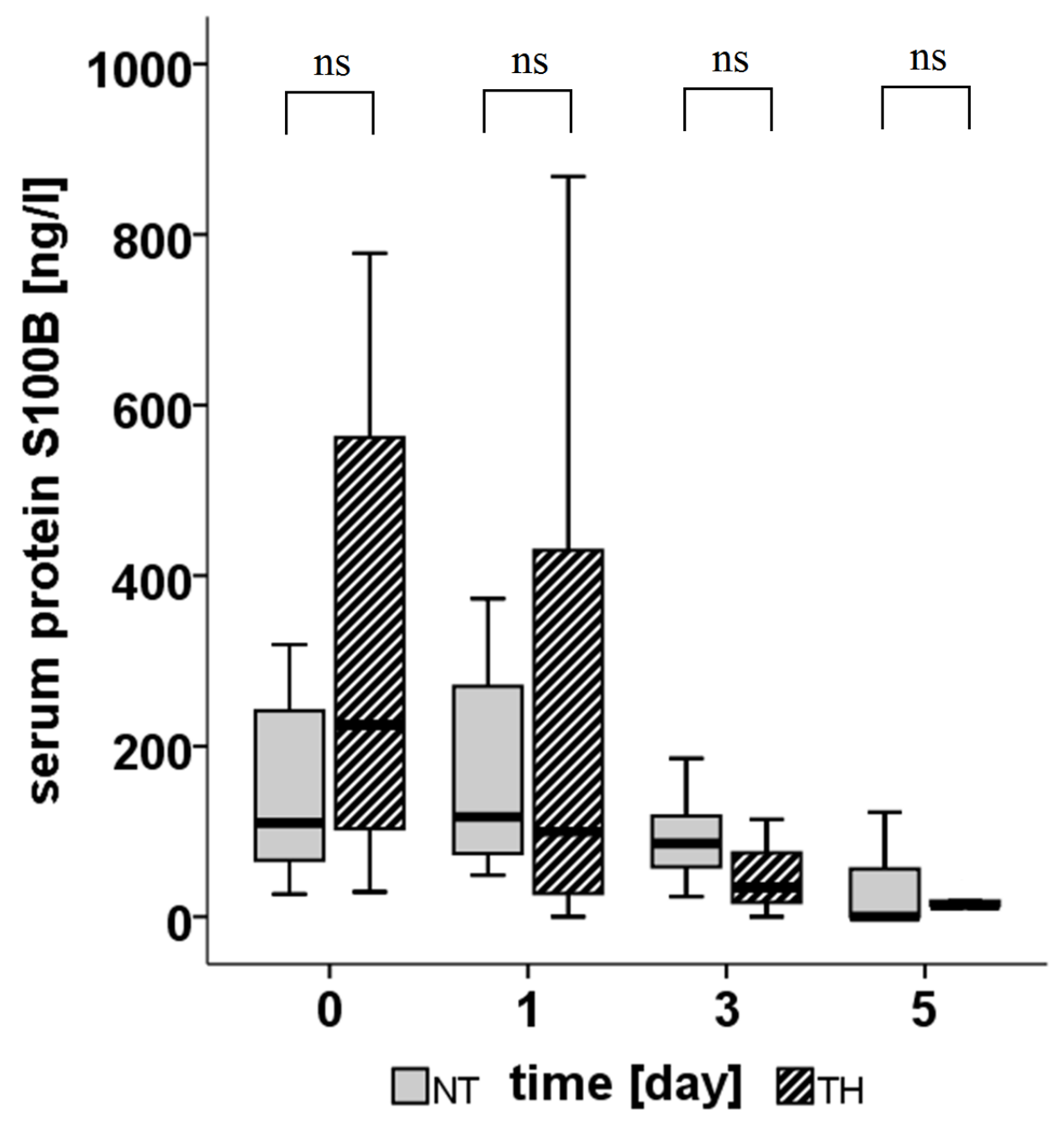

Figure 6. Serum protein S10oB levels in normothermic (NT - grey boxes) and therapeutic hypothermia (TH - striped boxes) groups. Data are expressed as median and inter-quartile range (IQR; standard $25^{\text {th }}$ $75^{\text {th }}$ percentile and $5^{\text {th }}$ and $95^{\text {th }}$ confidence interval). ${ }^{*} \mathrm{p}<0.05$, ns: nonsignificant 


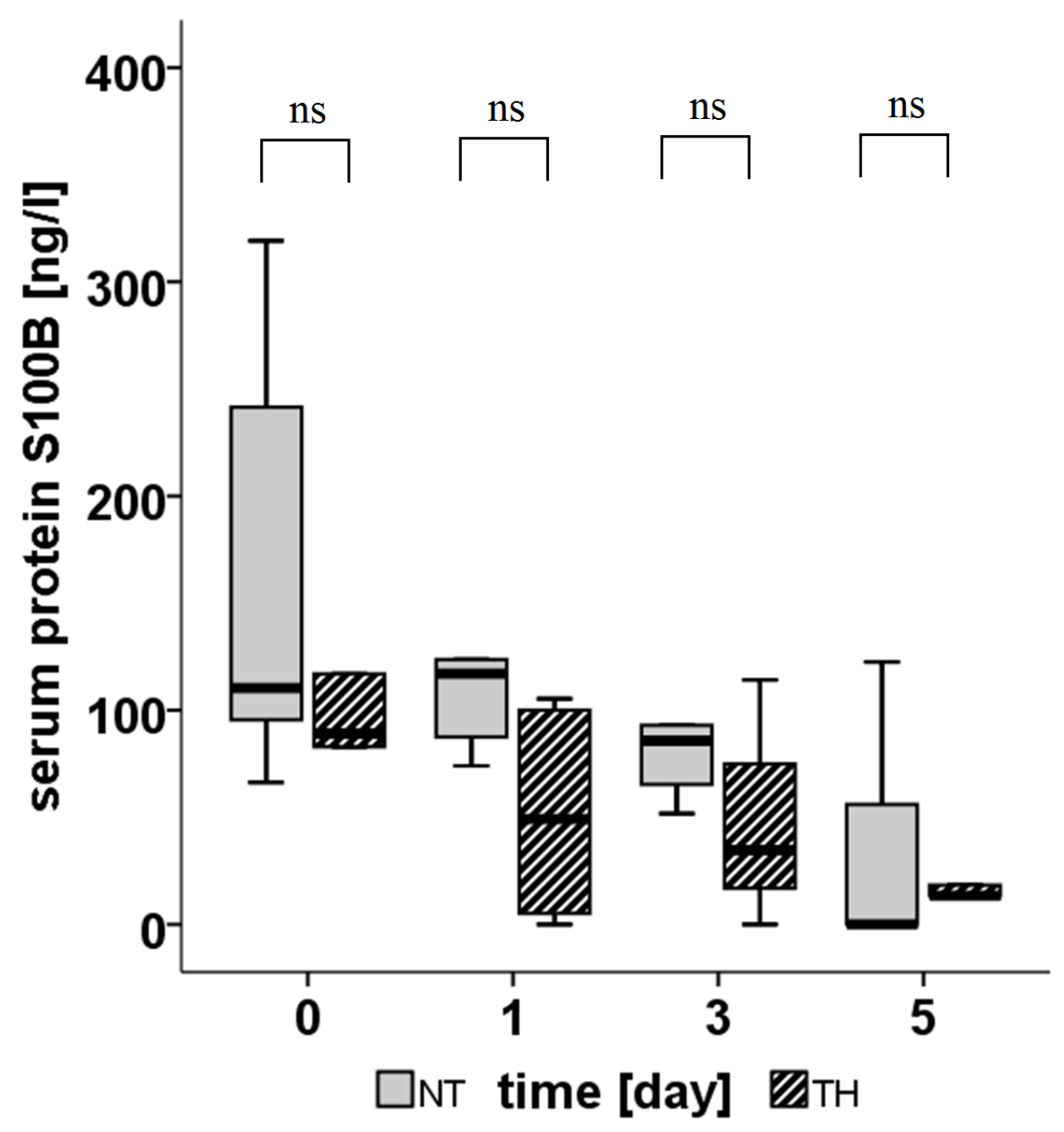

Figure 7. Serum protein S10oB levels in normothermic (NT - grey boxes) and therapeutic hypothermia ( $\mathrm{TH}$ - striped boxes) groups among survivors. Data are expressed as median and inter-quartile range (IQR; standard $25^{\text {th }}-75^{\text {th }}$ percentile and $5^{\text {th }}$ and $95^{\text {th }}$ confidence interval). ${ }^{*} \mathrm{p}<0.05$, ns: non-significant 
Table 1.A: Causes of cardiac arrest in the patient group $(n=57)$

\begin{tabular}{|c|c|c|}
\hline Cause of CA & $\begin{array}{l}\text { Patient } \\
\text { number }\end{array}$ & Prevalence \\
\hline Hypoxia & 27 & $47,3 \%$ \\
\hline Hypokalaemia & 7 & $12,4 \%$ \\
\hline Hypovolemia & 5 & $8,7 \%$ \\
\hline Acute myocardial infarction & 3 & $5,2 \%$ \\
\hline $\begin{array}{l}\text { Acute decompensation of dilated } \\
\text { cardiomyopathy }\end{array}$ & 3 & $5,2 \%$ \\
\hline Intoxication & 3 & $5,2 \%$ \\
\hline Acidosis & 2 & $3,5 \%$ \\
\hline $\begin{array}{l}\text { Subarachnoid haemorrhage with cerebral } \\
\text { oedema }\end{array}$ & 2 & $3,5 \%$ \\
\hline Hyperkalaemia & 1 & $1,8 \%$ \\
\hline Hypothermia & 1 & $1,8 \%$ \\
\hline Pneumothorax & 1 & $1,8 \%$ \\
\hline Thyrotoxic crisis & 1 & $1,8 \%$ \\
\hline $\begin{array}{l}\text { Mechanical irritation (by guide wire of } \\
\text { central venous catheter) }\end{array}$ & 1 & $1,8 \%$ \\
\hline
\end{tabular}


Table 1.B: Prevalence of chronic disorders in the patient group $(n=57)$

\begin{tabular}{|c|c|c|c|}
\hline & Disorder & $\begin{array}{l}\text { Patient } \\
\text { number }\end{array}$ & Prevalence \\
\hline \multirow{6}{*}{$\begin{array}{l}\text { Cardiovascular } \\
\text { disorders }\end{array}$} & Hypertension & 35 & $61,4 \%$ \\
\hline & Ischaemic heart disease & 14 & $24,6 \%$ \\
\hline & $\begin{array}{l}\text { Dilated } \\
\text { cardiomyopathy }\end{array}$ & 10 & $17,5 \%$ \\
\hline & Atrial fibrillation & 6 & $10,8 \%$ \\
\hline & Atrial flutter & 1 & $1,8 \%$ \\
\hline & $\begin{array}{l}\text { Third degree } \\
\text { atrioventricular block }\end{array}$ & 1 & $1,8 \%$ \\
\hline Diabetes mellitus & & 16 & $28 \%$ \\
\hline Chronic renal & Chronic haemodialysis & 4 & $7 \%$ \\
\hline failure & Other & 2 & $3,5 \%$ \\
\hline $\begin{array}{l}\text { Pulmonary } \\
\text { disorders }\end{array}$ & $\begin{array}{l}\text { Chronic pulmonary } \\
\text { obstructive disease }\end{array}$ & 16 & $28 \%$ \\
\hline & Asthma bronciale & 1 & $1,8 \%$ \\
\hline & Silicosis & 2 & $3,5 \%$ \\
\hline
\end{tabular}


Table 2.: 30-day-mortality depending on Glasgow Coma Scale at intensive care unit admission

\section{0-day-mortality}

\begin{tabular}{ccccc} 
& & & & Total \\
& & Died & Survived & \\
\hline GCS at & $<6$ & $35(80 \%)$ & $9(20 \%)$ & 44 \\
ICU & & & & 13 \\
admission & $\geq 6$ & $7(58 \%)$ & $6(42 \%)$ & \\
\hline Total & & & 57 \\
\hline
\end{tabular}

GCS: Glaggow Coma Scak, ICU: intensive care unit

Corresponding author:

Ákos Mérei

University of Pécs

Department of Anaesthesia and Intensive Therapy

Rákóczi str. 2.,Pécs, Baranya, Hungary, HU-7623

Phone: 0036-72/533-127

Fax: 0036-72/533-117

E-mail: merei.akos@gmail.com 
Article printed from Signa Vitae: http://www.signavitae.com

URL to article: http://www.signavitae.com/2015/12/effects-oftherapeutic-hypothermia-and-kinetics-of-serum-proteins1oob-after-cardiopulmonary-resuscitation/

Copyright (C) 2015 Signa Vitae. All rights reserved. 